\title{
A new indolocarbazole derivative in melanoma and carcinoma lung in vivo treatment
}

Anna Lantsova ${ }^{1}$, Irina Golubeva ${ }^{1}$, Larisa Borisova ${ }^{1}$, Lyudmila Nikolaeva ${ }^{1,2^{*}}$, Lydia Ektova ${ }^{1}$, Maria Dmitrieva ${ }^{1}$ and Olga Orlova ${ }^{1}$

\begin{abstract}
Objective: The current scientific research direction is development of drugs with a targeted effect on malignant tumors. One of the promising groups is indolocarbazoles and their derivatives, which can initiate various tumor cell death pathways. Russian scientists from N. N. Blokhin National Medical Research Center of Oncology of the Ministry of Health of Russian Federation has developed a new experimental drug form of the original compound LCS 1269 with cytotoxic and antiangiogenic properties, blocking vasculogenic mimicry in tumor. The study aim is the experimental drug form LCS 1269 antitumor activity on models of transplantable mouse tumors B-16 melanoma and Lewis epidermoid lung carcinoma (LLC) with different routes and modes of administration.
\end{abstract}

Material and methods: Female $\mathrm{F} 1$ hybrid mice $\left(\mathrm{C}_{57} \mathrm{Bl} / 6 \times \mathrm{DBA} / 2\right)$ and male and female linear mice $\mathrm{C}_{57} \mathrm{BL} / 6$ were used for management of tumor strains. Mice were obtained from N. N. Blokhin National Medical Research Center of Oncology of the Ministry of Health of Russian Federation vivarium. The antitumor effect was assessed by tumor growth inhibition (TGI) and increase of treated animal's life span (ILS) compared to the control.

Results: The experimental drug form showed high antitumor activity when administered intravenously once at doses of 100 and $120 \mathrm{mg} / \mathrm{kg}(\mathrm{TGl}=98-82 \%$ and TGl $=95-77 \%$, respectively, ILS $=24 \%, p<0.05)$ on melanoma B-16 mice. On LLC mice, the experimental drug form showed that the intravenous administration route was effective in the range of doses from 60 to $80 \mathrm{mg} / \mathrm{kg}$ with a 5 day administration regimen with an interval of $24 \mathrm{~h}$. A dose of 70 $\mathrm{mg} / \mathrm{kg}$ had maximum effect at the level of $\mathrm{TGl}=96-77 \%(p<0.05)$ with its retention for 20 days after the end of treatment.

Conclusion: The studies have shown that the new compound LCS 1269 in the original drug form, has a pronounced antitumor activity and significantly reduces the volume of tumor mass both on melanoma B-16 and on LLC. It allows us to recommend continue the search for sensitivity of animal transplantable tumors to LCS 1269.

Keywords: Indolocarbazole derivatives, Antitumor activity, Inhibitor, Vasculogenic mimicry, Topoisomerase, Angiogenesis

\footnotetext{
* Correspondence: alima91@yandex.ru

1 Research Institute of Experimental Diagnostics and Therapy of Tumors, N.

N. Blokhin National Medical Research Center of Oncology Kashirskoe

shosse, 24115478 Moscow Russia

2 Department of Pharmaceutical Technology and Pharmacology

Sechenov University, 8/2 Trubeckaya str. 119991 Moscow Russia
}

(C) The Author(s). 2021 Open Access This article is licensed under a Creative Commons Attribution 4.0 International License, which permits use, sharing, adaptation, distribution and reproduction in any medium or format, as long as you give appropriate credit to the original author(s) and the source, provide a link to the Creative Commons licence, and indicate if changes were made. The images or other third party material in this article are included in the article's Creative Commons licence, unless indicated otherwise in a credit line to the material. If material is not included in the article's Creative Commons licence and your intended use is not permitted by statutory regulation or exceeds the permitted use, you will need to obtain permission directly from the copyright holder. To view a copy of this licence, visit http://creativecommons.org/licenses/by/4.0/. The Creative Commons Public Domain Dedication waiver (http://creativecommons.org/publicdomain/zero/1.0/) applies to the data made available in this article, unless otherwise stated in a credit line to the data. 


\section{Introduction}

An urgent direction for scientific research is the development of drugs with a targeted effect on malignant neoplasms. One of particularly promising groups with such properties is indolocarbazoles and their derivatives, which can trigger various pathways of tumor cell death. Indolocarbazoles are known to have the ability to inhibit topoisomerases I and II involved in the control of DNA replication and transcription $[1,2]$.

Russian researchers at the N.N. Blokhin National Medical Research Center of Oncology, Ministry of Health of the Russian Federation, synthesized indolo [2,3-a]pyrrolo [3,4-c] carbazole-5,7-diones-n-\{12-( $\beta$-d-xylopyranosyl $)-5$, 7-dioxo-indolo [2,3-a]pyrrolo [3,4-c] carbazole-6ylspyridine-2-carboxamide (LCS 1269) [3], a new compound with cytotoxic and antiangiogenic properties, which blocks tumor vasculogenic mimicry (VM) [4] (Fig. 1).

In vitro studies LCS 1269 effectively changed VM and suppressed the angiogenesis mechanism associated with vascular endothelial growth factor (VEGF), resulting in a decreased tumor vascularization and a reduced tumor growth [5-7].

Vascular mimicry is the ability of aggressive tumor cells to form vascular-like channels, separated by the basement membrane, without the involvement of endothelial cells or fibroblasts. The formation of such structures reflects the unique ability of cells with a highly malignant cell phenotype. The appearance of the network of such channels inside a tumor has been

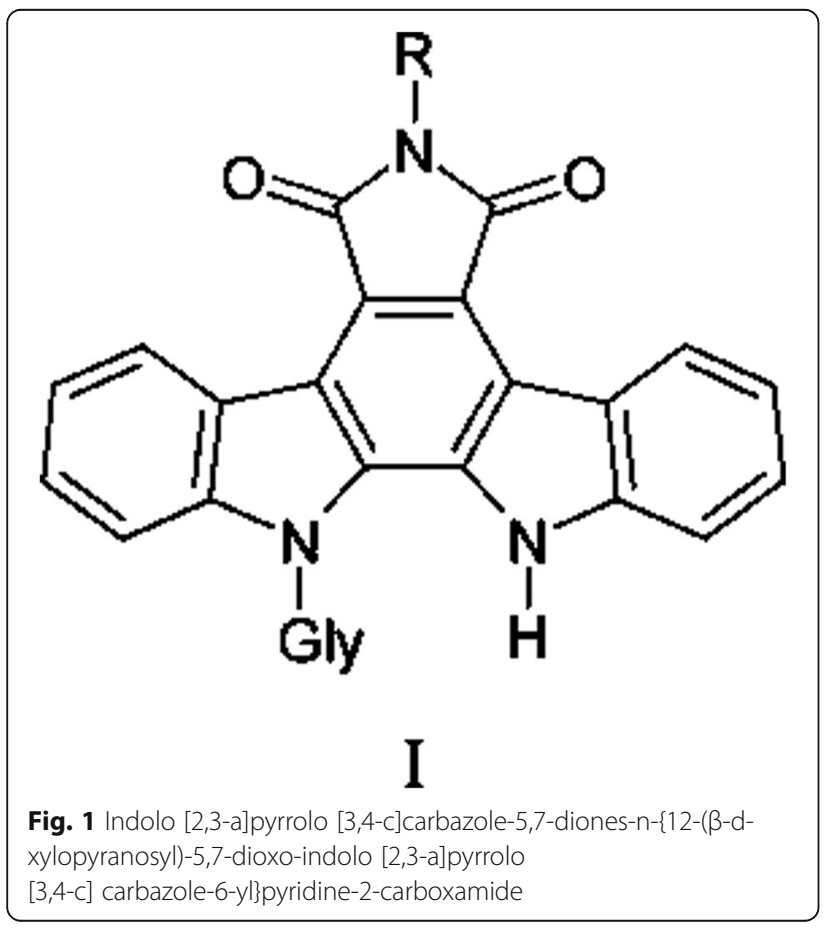

hypothesized to support homeostasis and prevent early necrosis in a tumor [8].

Clinical trials of drugs that potentially reduce blood supply to the tumor have shown that antiangiogenic therapy is not always effective [9]. One potential cause of the survival of tumor cells is the heterogeneity of blood vessels: angiogenesis in tumors takes place in the altered extracellular matrix in the presence of uncontrolled mitogenic stimulation. It leads to the formation of defective vessels often with a broken endothelial lining. In tumor vessels, the endothelium can be absent or replaced by tumor cells. The phenomenon of VM explains the insensitivity of many malignant tumors to antiangiogenic therapy. VM is seen in almost all malignancies, and its presence correlates with the risk of metastasis and poor clinical prognosis [10].

Blockage of VM will increase the effectiveness of antiangiogenic therapy, help overcome the resistance of tumor cells to cytotoxic therapy, and prevent the transition of the tumor to a phase of more aggressive growth by reducing its plasticity. It is assumed that the antitumor effect of antiangiogenic therapy will be more pronounced if antiangiogenic agents are combined with VM inhibitors [11-17].

The relevance of our development is justified by the absence of topoisomerase I and/or II inhibitors in Russian clinical practice, while an array of chemotherapy drugs with these properties, such as irinotecan, topotecan, etoposide and teniposide, are extensively used by oncologists [14-17].

The unique mechanism of antitumor activity of LCS 1269 is explained by its dual mechanism of action, i.e. inhibition of the tumor topoisomerase and blockage of VM in the tumor. These properties justify the relevance of developing a parenteral formulation of LCS 1269. Compounds from this group are poorly soluble in water, and the creation of a drug with high bioavailability is an important and time-consuming process.

Researchers at the N.N. Blokhin National Medical Research Center of Oncology, Ministry of Health of the Russian Federation, have proposed a new experimental formulation of LCS 1269. Our research has led to the development of a stable experimental formulation containing $5 \mathrm{mg} / \mathrm{ml}$ of the active substance together with dimethyl sulfoxide (DMSO) (5\%), a complex solvent (5\%), ethanol (20\%) and Kollidon 17PF (20\%), a solubilizing and complexing agent.

This article describes a study of the specific activity of the experimental LCS 1269 formulation in transplantable mouse tumor models of B16 melanoma and Lewis lung carcinoma (LLC).

Melanoma is a leading cause of mortality from skin cancer and has a poor prognosis. Despite rapid advances in the treatment of this tumor type, the efficacy of 
current chemo-/targeted-therapies is still limited owing to the lack of sufficient drug accumulation in the tumor tissue and development of chemo-resistance [18-22].

Lung cancer is a malignancy with a high morbidity and mortality rate, and affected patients have low survival and poor prognosis. The therapeutic approaches for the treatment of this cancer, including radiotherapy and chemotherapy, are not particularly effective partly due to late diagnosis. Therefore, the search for new diagnostic and prognostic tools is a critical issue [23].

The aim of this study was to evaluate the antitumor activity of an original Russian antitumor indolocarbazole derivative intended for a targeted cancer therapy by assessing its antitumor effect on B16 melanoma and LLC.

\section{Materials and methods Laboratory animals}

In our experiment we used (C57BL/6xDBA/2) F1 female mice and C57BL/6 male and female mice, with the latter being used to inoculate tumor cells. The mice were obtained from the vivarium at the N.N. Blokhin National Medical Research Center of Oncology. The mice were kept in conventional conditions on briquetted feed and provided constant access to water [24].

The animals were divided into experimental $(N=6-8)$ and control groups (untreated, $N=10$ ). All animal protocols were approved by the Institutional Animal Care and Use Committee at the IBMC.

\section{Models of tumor growth}

The antitumor activity of the study compound LCS 1269 was evaluated on two transplantable murine tumors, i.e. B16 melanoma and LLC.

B16 melanoma is a non-immunogenic tumor that has been maintained in C57BL/6 mice. The tumor arose spontaneously in 1954 in the skin at the base of the ear of a C57BL/6 mouse. This cancer cell line was obtained in 1975 from the frozen tumor bank (USA). It has a heterogeneous cell population, including both highly pigmented sites and areas with little or no melanin. It metastasizes to the lungs in $60-90 \%$ of cases, and sometimes to the liver and spleen. The average life span of animals with this tumor is $25-30$ days.

LLC grows rapidly, metastasizes to the lungs in 100\% of cases, and is selectively sensitive to certain groups of anticancer drugs. LLC occurred spontaneously in a C57BL6 mouse in 1951. This cancer cell line was obtained from the U.S. National Cancer Institute in September 1973. The tumor consists of polymorphic cells, most of which are round in shape. A significant part of the cell is occupied by a nucleus with large nucleoli and large condensed chromatin bodies. LLC has been maintained in C57BL/6 mice. The average life span of animals with this tumor is 24 days.

The cancer cell lines were obtained from the cancer cell line bank at the N.N. Blokhin National Medical Research Center of Oncology. The B16 melanoma cell line was maintained in C57BL/6 female mice, who received subcutaneous grafts every $12-14$ days, according to the standard procedure of serial grafting. The LLC cell line was maintained in C57BL/6 males, who received intramuscular grafts every 12-14 days [25]. Experiments were started from the fourth passage of the tumors in vivo. In our experiment, tumor transplantation was performed according to the standard method used at the N.N. Blokhin National Medical Research Centre of Oncology. Tumors were transplanted to (C57BL/6xDBA/2) F1 hybrid mice. A total of $0.5 \mathrm{ml}(50 \mathrm{mg})$ of tumor cell suspension (a 1/10 dilution in medium 199) was injected subcutaneously (s.c.) in the right axillary region [11, 12]. Treatment was started $48 \mathrm{~h}$ after transplantation [25, 26].

\section{Study compound}

The experimental formulation of the study compound contained LCS $12695 \mathrm{mg}$, DMSO 5\%, Kollidon 17PF $20 \%$, ethanol $20 \%$, and water up to $100 \%$.

\section{Dosing regimens and routes of administration}

The antitumor effect of LCS 1269 on B16 melanoma and LLC was studied by administering this agent in an experimental injectable formulation through different routes of administration using the following dosing regimens:

- intravenously (i.v.) daily for 5 days $(24 \mathrm{~h} \times 5)$ at doses of 60,70 or $80 \mathrm{mg} / \mathrm{kg}$ (total doses 300,350 or $400 \mathrm{mg} / \mathrm{kg}$, respectively);

- i.v. at a single dose of 100 or $120 \mathrm{mg} / \mathrm{kg}$ (for B16 melanoma-bearing mice) and 150 or $180 \mathrm{mg} / \mathrm{kg}$ (for LLC-bearing mice);

- intraperitoneally (i.p.) daily for 5 days $(24 \mathrm{~h} \times 5)$ at a dose of $60 \mathrm{mg} / \mathrm{kg}$ (total dose $300 \mathrm{mg} / \mathrm{kg}$ );

- two i.p. doses of 100 or $120 \mathrm{mg} / \mathrm{kg}$ at a $96-\mathrm{h}$ interval (total doses 200 or $240 \mathrm{mg} / \mathrm{kg}$, respectively);

- s.c. daily for 5 days $(24 \mathrm{~h} \times 5)$ at a dose of $60 \mathrm{mg} / \mathrm{kg}$ (total dose $300 \mathrm{mg} / \mathrm{kg}$ );

- two s.c. doses of 100 or $120 \mathrm{mg} / \mathrm{kg}$ at a 96-h interval (total doses of 200 or $240 \mathrm{mg} / \mathrm{kg}$, respectively);

- two oral doses of $120 \mathrm{mg} / \mathrm{kg}$ at a $96-\mathrm{h}$ interval (total dose of $240 \mathrm{mg} / \mathrm{kg}$ );

- per os daily for 5 days $(24 \mathrm{~h} \times 5)$ at doses of 130,150 or $200 \mathrm{mg} / \mathrm{kg}$ (total doses 650,750 or $1000 \mathrm{mg} / \mathrm{kg}$, respectively). 
These doses were selected based on the in vitro and in vivo pre-screening assessment of the antitumor activity of LCS 1269 substance, as well as the dose regimens used for LCS 1208, another experimental drug of this class [27].

\section{Criteria for assessing antitumor activity}

The following criteria for assessing antitumor activity were applied: tumor growth inhibition (TGI, \%) and percentage increase in life span (ILS, \%) of the test animals compared with the control animals $[25,26]$.

The antitumor effect was assessed by measurements of tumor volume, which were done every 3-4 days, depending on tumor growth rate.

The tumor volume was calculated by multiplying its maximum dimensions in three orthogonal directions (length, $l$; width, $w$, height, $h$ ). This parameter was calculated for all animals.

TGI was calculated using the following formula (1):

$$
\operatorname{TGI}(\%)=(\mathrm{Vc}-\mathrm{Ve}) / \mathrm{Vc} \times 100,
$$

where: TGI - tumor growth inhibition;

$\mathrm{Vc}$ - mean tumor volume in the control group $\left(\mathrm{mm}^{3}\right)$;

$\mathrm{Ve}-$ mean tumor volume in the experimental group $\left(\mathrm{mm}^{3}\right)$.

ILS was calculated using the following formula (2):

ILS $(\%)=($ MLSc - MLSe $) /$ MLSc $\times 100,(2)$.

where: ILS - increase in life span;

MLSc - mean life span of the animals in the control group (days);

MLSe - mean life span of the animals in the experimental group (days).

The following minimal efficacy criteria were used: TGI $\geq 50 \%$ and ILS $\geq 25 \%$ for animals with a solid tumor. The effective dose was defined as the dose of the study compound resulting in TGI $\geq 70 \%$ persistent for at least 7 days post-treatment $[25,26]$.

\section{Evaluation of treatment tolerability in tumor-bearing mice}

The animals were monitored until death. The condition of the animals was evaluated by daily visual inspections. The tolerability of this chemotherapeutic compound was assessed by the condition and behavior of the mice. The toxicity of the regimens and doses used in the study was assessed by time to death in the experimental group compared with that in the control group.

The statistical analysis was done using the Statistica 6.0 software (StatSoft, Tulsa, OK), with study data being analyzed by the Student's t-test. The differences were considered significant at $p \leq 0.05$.

\section{Results}

The search for active anticancer ingredients starts with the study of chemical compounds obtained by a random or streamlined synthesis, which is followed by a twostage initial selection, including in vitro pre-screening and in vivo screening of active substances. If a compound demonstrates an antitumor activity, then it undergoes the standardization process, and the possibility for creating a dosage form is assessed. If a dosage form is created, it is then evaluated in in-depth preclinical and clinical studies. Evaluation of the efficacy and assessment of the specific activity of the new drug product are performed as one of the stages of preclinical studies. For anticancer drugs, this includes search for sensitive tumors, an identification of the most effective mode of administration and selection of the therapeutic dose range by comparing doses causing death of animals and non-lethal doses providing an antitumor effect. Our research was focused on this stage.

This article presents data about studying tumors sensitive to a new experimental dosage form of LCS 1269, which were obtained from experiments performed on models of transplantable murine tumors (B16 melanoma and LLC).

\section{Antitumor efficacy of the experimental formulation of LCS 1269 on melanoma B16 mice}

The antitumor efficacy of LCS 1269 was studied by administering this agent in an experimental formulation to mice with B16 melanoma through different routes of administration using different dosing regimens (Table 1 , Fig. 2).

When administered in its experimental formulation at a daily dose of $60 \mathrm{mg} / \mathrm{kg}$ for 5 days (total dose $300 \mathrm{mg} /$ $\mathrm{kg}$ ), LCS 1269 showed a pronounced long-term antitumor effect with TGI $90-66 \%$ ( $p<0.05$ compared with control), which was maintained until day 16 post- treatment. However, $17 \%$ of the animals in this group showed signs of toxicity and died. Toxicity was assessed by mean spleen weight in the treatment group (mean weight $95.2 \pm 46.1 \mathrm{mg}$ ) compared to the control group (mean weight $109.3 \pm 37.9 \mathrm{mg}$ ). Normal spleen weight in healthy animals is about $190.2 \pm 35.3 \mathrm{mg}$.

After single i.v. administration of LCS 1269 at $100 \mathrm{mg} /$ $\mathrm{kg}$ or $120 \mathrm{mg} / \mathrm{kg}$, the highest antitumor effect was observed with TGI $98-82 \%$ and $95-77 \%(p<0.05)$, respectively, which persisted until day 16 post-treatment. No animal deaths were observed.

When administered at a dose of $60 \mathrm{mg} / \mathrm{kg}$ i.p. under a 24-h $\times 5$ regimen, LCS 1269 showed a high long-term antitumor effect with TGI 95-73\% $(p<0.05)$, which persisted until day 16 post-treatment, and ILS 26\% $(p<$ 0.05). No deaths were observed. 
Table 1 Antitumor efficacy of the experimental formulation of LCS 1269 for B16 melanoma

\begin{tabular}{|c|c|c|c|c|c|c|c|c|}
\hline \multirow[t]{2}{*}{$\begin{array}{l}\text { Route of } \\
\text { administration }\end{array}$} & \multirow{2}{*}{$\begin{array}{l}\text { Dose }(\mathrm{mg} / \mathrm{kg}) / \\
\text { interval }(\mathrm{h}) \mathrm{x} \\
\text { number of } \\
\text { administrations }\end{array}$} & \multicolumn{5}{|c|}{$\begin{array}{l}\text { TGI (\%) } \\
\text { Days post-treatment }\end{array}$} & \multirow[t]{2}{*}{$\begin{array}{l}\text { ILS } \\
(\%)\end{array}$} & \multirow{2}{*}{$\begin{array}{l}\text { Death } \\
\text { of } \\
\text { animals } \\
(\%)\end{array}$} \\
\hline & & 1 & 4 & 8 & 12 & 16 & & \\
\hline \multirow[t]{3}{*}{ i.v. } & $60 / 24 \times 5$ & $90^{*}$ & $92^{*}$ & $67^{*}$ & $58^{*}$ & $66^{*}$ & - & 17 \\
\hline & $100 \times 1$ & $98^{*}$ & $94^{*}$ & $81^{*}$ & $73^{*}$ & $82^{*}$ & $24^{*}$ & 0 \\
\hline & $120 \times 1$ & $95^{*}$ & $94^{*}$ & $85^{*}$ & $79^{*}$ & $77^{*}$ & 4 & 0 \\
\hline i.p. & $60 / 24 \times 5$ & $95^{*}$ & $98^{*}$ & $83^{*}$ & $76^{*}$ & $73^{*}$ & $26^{*}$ & 0 \\
\hline per os & $120 / 96 \times 2$ & $66^{*}$ & $67^{*}$ & 43 & 47 & $64^{*}$ & 9 & 0 \\
\hline \multirow[t]{2}{*}{ s.c. } & $60 / 24 \times 5$ & $83^{*}$ & $78^{*}$ & 45 & 41 & $60^{*}$ & $25^{*}$ & 0 \\
\hline & $120 / 96 \times 2$ & $78^{*}$ & $75^{*}$ & 42 & 32 & $63^{*}$ & - & 50 \\
\hline
\end{tabular}

Note: ${ }^{*} p<0.05$ compared with control

Administration of LCS 1269 at two oral doses of 120 $\mathrm{mg} / \mathrm{kg}$ (total dose $240 \mathrm{mg} / \mathrm{kg}$ ) at a $96-\mathrm{h}$ interval resulted in a moderate antitumor effect, with TGI persisting at $66-64 \%(p<0.05)$ until day 16 post-treatment. No deaths were reported. No increase in life span was seen.

Daily s.c. administration of LCS 1269 at a dose of 60 $\mathrm{mg} / \mathrm{kg}$ (total dose of $300 \mathrm{mg} / \mathrm{kg}$ ) for 5 days produced a high short-term antitumor effect with TGI 83-60\% ( $p<$ $0.05)$, which persisted until day 4 post-treatment; a minimal effect (TGI 45-60\%, $p<0.05$ ) was observed until day 16 of observation. The second minimal efficacy criterion (ILS $25 \%$ ) was also reached $(p<0.05)$. No deaths of animals were reported. When administered at two s.c doses at a 96-h interval, LCS 1269 produced toxicity at the higher dose $(120 \mathrm{mg} / \mathrm{kg})$, despite the lower course dose of $240 \mathrm{mg} / \mathrm{kg}$, and caused the death of $50 \%$ of the animals in this group.

\section{Antitumor efficacy of the experimental formulation of LCS 1269 on LLC}

The efficacy of LCS 1269 for LLC was studied in a wide range of doses $(60 \mathrm{mg} / \mathrm{kg}$ to $200 \mathrm{mg} / \mathrm{kg}$ ), using different routes of administration and dosing regimens (Table 2, Fig. 3).

A five-day course of daily s.c. LCS $1269(60 \mathrm{mg} / \mathrm{kg}$ at a 24-h interval) given in its experimental formulation was associated with TGI $82 \%$ immediately post-treatment, which persisted at 58\% ( $p<0.05$ compared with control) until day 20 of observation, and with ILS 34\%. Administration of two s.c. doses of $100 \mathrm{mg} / \mathrm{kg}$ or $120 \mathrm{mg} / \mathrm{kg}$ at a 96-h interval resulted in a high antitumor effect, i.e. TGI ranging from 80 to $68 \%$ to $86-63 \%(p<0.05)$ over a period of 20 days (Table 2).

Evaluation of the antitumor activity of the study compound against LLC was also performed after a five-day course of daily oral LCS 1269 given in its experimental formulation at a 24-h interval. It showed that administration at doses of $130 \mathrm{mg} / \mathrm{kg}$ and $150 \mathrm{mg} / \mathrm{kg}$ was associated with TGI $64-52 \%$ and $69-61 \%(p<0.05)$, respectively, which persisted until day 8 post-treatment (Table 2).

The data obtained in this study showed that the highest antitumor effect on murine LLC was achieved with a five-dose course of LCS 1269 given in its experimental

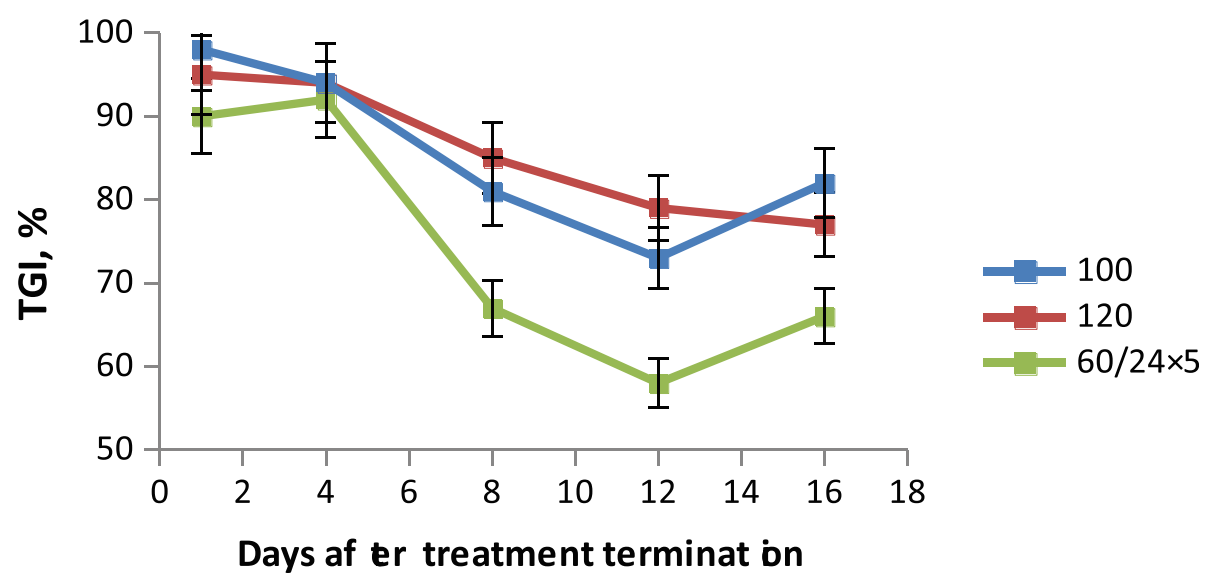

Fig. 2 Correlation between TGI in murine B16 melanoma and i.v. dose of LCS 1269 
Table 2 Antitumor efficacy of the experimental formulation of LCS 1269 for LLC

\begin{tabular}{|c|c|c|c|c|c|c|c|c|c|}
\hline \multirow[t]{2}{*}{$\begin{array}{l}\text { Route of } \\
\text { administration }\end{array}$} & \multirow{2}{*}{$\begin{array}{l}\text { Dose }(\mathrm{mg} / \mathrm{kg}) / \\
\text { interval }(\mathrm{h}) \mathrm{x} \\
\text { number of } \\
\text { administrations }\end{array}$} & \multicolumn{6}{|c|}{$\begin{array}{l}\text { TGI (\%) } \\
\text { Days post-treatment }\end{array}$} & \multirow[t]{2}{*}{$\begin{array}{l}\text { ILS } \\
\text { (\%) }\end{array}$} & \multirow{2}{*}{$\begin{array}{l}\text { Death } \\
\text { of } \\
\text { animals } \\
(\%)\end{array}$} \\
\hline & & 1 & 4 & 8 & 12 & 16 & 20 & & \\
\hline \multirow[t]{3}{*}{ s.c. } & $60 / 24 \times 5$ & $78^{*}$ & $78^{*}$ & $66^{*}$ & $61^{*}$ & 45 & $58^{*}$ & $34^{*}$ & 0 \\
\hline & $100 / 2 \times 96$ & $80^{*}$ & $75^{*}$ & $69^{*}$ & $64^{*}$ & $64^{*}$ & $68^{*}$ & $15^{*}$ & 0 \\
\hline & $120 / 2 \times 96$ & $86^{*}$ & $79^{*}$ & $72^{*}$ & $71^{*}$ & $64^{*}$ & $63^{*}$ & $19^{*}$ & 0 \\
\hline \multirow[t]{3}{*}{ per os } & $130 / 24 \times 5$ & $64^{*}$ & $56^{*}$ & $52^{*}$ & $31^{*}$ & $35^{*}$ & 24 & - & 0 \\
\hline & $150 / 24 \times 5$ & $69^{*}$ & $64^{*}$ & $61^{*}$ & $44^{*}$ & $42^{*}$ & $43^{*}$ & $13^{*}$ & 0 \\
\hline & $200 / 24 \times 5$ & $45^{*}$ & $56^{*}$ & $48^{*}$ & $41^{*}$ & 28 & $45^{*}$ & - & 0 \\
\hline \multirow[t]{5}{*}{ i.v. } & $60 / 24 \times 5$ & $94^{*}$ & $68^{*}$ & $57^{*}$ & $61^{*}$ & $56^{*}$ & $51^{*}$ & $11^{*}$ & 0 \\
\hline & $70 / 24 \times 5$ & $96^{*}$ & $86^{*}$ & $80^{*}$ & $81^{*}$ & $61^{*}$ & $77^{*}$ & $8^{*}$ & 0 \\
\hline & $80 / 24 \times 5$ & $71^{*}$ & $76^{*}$ & $60^{*}$ & $54^{*}$ & $39^{*}$ & $71^{*}$ & $9^{*}$ & 0 \\
\hline & $150 \times 1$ & $81^{*}$ & $49^{*}$ & 24 & 35 & 13 & 27 & - & 0 \\
\hline & $180 \times 1$ & - & - & - & - & - & - & - & 86 \\
\hline \multirow[t]{3}{*}{ i.p. } & $60 / 24 \times 5$ & $63^{*}$ & $60^{*}$ & $52^{*}$ & 37 & 39 & 41 & $23^{*}$ & 0 \\
\hline & $100 / 2 \times 96$ & $53^{*}$ & $53^{*}$ & $49^{*}$ & $47^{*}$ & 36 & $47^{*}$ & $27^{*}$ & 0 \\
\hline & $120 / 2 \times 96$ & $61^{*}$ & $73^{*}$ & $68^{*}$ & $61^{*}$ & $66^{*}$ & $67^{*}$ & - & 0 \\
\hline
\end{tabular}

Note: ${ }^{*} p<0.05$ compared with control

formulation at daily i.v. doses of $60-80 \mathrm{mg} / \mathrm{kg}$ (total dose $300-400 \mathrm{mg} / \mathrm{kg}$, respectively). The maximum effectTGI $96 \%(p<0.05)$ persistent at $77 \%$ until day 20 posttreatment-was achieved with the dose of $70 \mathrm{mg} / \mathrm{kg}$. A single i.v. dose of $180 \mathrm{mg} / \mathrm{kg}$ produced toxicity-related deaths of $86 \%$ of the mice in this group 4 days after treatment. Toxicity was assessed by the mean spleen weight in the treatment group (mean weight $33.3 \pm 11.4$ $\mathrm{mg}$ ) compared with the control (mean weight $110.4 \pm$ $53.7 \mathrm{mg})$.
Comparison of two i.p. dosing regimens-five doses at a 24-h interval and two doses at a $96 \mathrm{~h}$ interval-showed that the highest antitumor effect was achieved with two doses of $120 \mathrm{mg} / \mathrm{kg}$ given at a 96-h interval. TGI was $61 \%$ and persisted at $67 \%(p<0.05)$ until day 20 posttreatment.

\section{Discussion}

Thus, evaluation of the antitumor activity of the LCS 1269 experimental formulation in transplantable murine

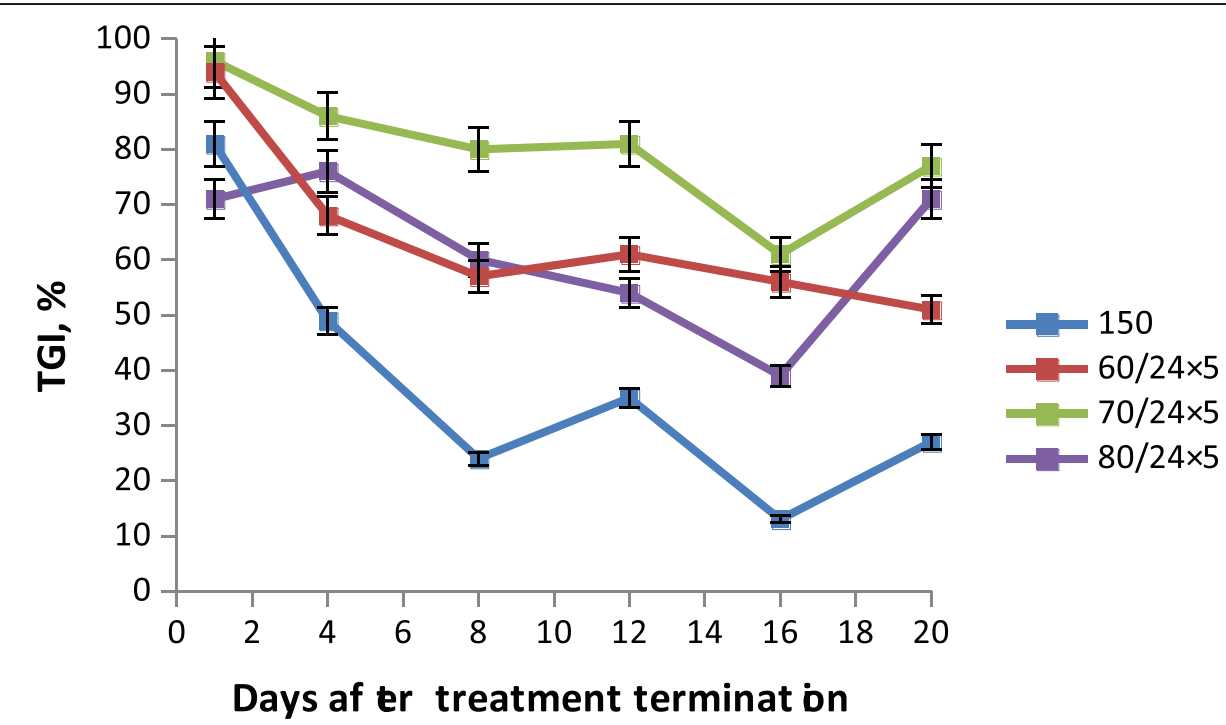

Fig. 3 Correlation between TGI in murine LLC and i.v. dose of LCS 1269 
tumors showed that it exerted a high antitumor effect against B16 melanoma when administered at single i.v. doses of $100 \mathrm{mg} / \mathrm{kg}$ or $120 \mathrm{mg} / \mathrm{kg}$ (i.e. TGI $98-82 \%$, ILS $24 \%$ and TGI $95-77 \%$, respectively; $p<0.05$ ); as well as at i.p. doses of $60 \mathrm{mg} / \mathrm{kg}$ at 24-h intervals for 5 days (TGI 95-73\%, ILS 26\%, $p<0.05$ ). This effect lasted for 16 days after the end of treatment.

In LLC-bearing mice, the most pronounced antitumor effect was observed after a five-day course of i.v. LCS 1269 given at daily doses of $70 \mathrm{mg} / \mathrm{kg}$ at a $24-\mathrm{h}$ interval, i.e. TGI $96-77 \%(p<0.05)$, which persisted until day 20 post-treatment.

As shown in Tables 1 and 2, deaths were reported in mice who received the drug at the highest total doses $(240 \mathrm{mg} / \mathrm{kg}$ and $300 \mathrm{mg} / \mathrm{kg})$ and at the highest single dose $(180 \mathrm{mg} / \mathrm{kg})$, i.e. doses at which exposure to the active substance of LCS 1269 was associated with general toxicity rather than an antitumor effect. This was supported by a decreased mean spleen weight in the experimental group compared with the control group of healthy animals (mean spleen weight in mice $190 \mathrm{mg}$ ).

The results of this experimental study are comparable with other authors' data about the antiproliferative activity of different indolocarbazole derivatives [12-17].

This supports the necessity and urgency of further preclinical studies of the new experimental formulation of LCS 1269. These data also suggest that this formulation may be effective against a wider range of transplantable animal tumors.

\section{Conclusion}

Studies have shown a marked antitumor effect of the new LCS 1269 drug product in its original formulation against both murine B16 melanoma and LLC. It was also proven to reduce significantly the tumor volume, which suggests a further search for transplantable animal tumors sensitive to LCS 1269 .

\section{Abbreviations}

DMSO: Dimethylsulfoxide; ip: Intraperitoneally; iv: Intravenously; ILS: Increase in life span; LLC: Lewis lung carcinoma; TGI: Tumor growth inhibition; VM: Vasculogenic mimicry

\section{Acknowledgments}

The authors of this manuscript have reviewed and approved its content and have all made substantive intellectual contributions to the work. Further, they all affirm that the article is original, is not under consideration by another journal, has not been previously reviewed or published.

\section{A statement to confirm that all methods were carried out in accord- ance with relevant guidelines and regulations \\ The authors confirm that all methods were carried out in accordance with relevant guidelines and regulations.}

\section{Authors' contributions}

Lantsova A., Nikolaeva L., Dmitrieva M.: research design, design of the manuscript. Golubeva I., Borisova L.: obtaining and analyzing data. Ektova L., Orlova O.: synthesis and analysis of substance, verification of the final version of the manuscript. The author (s) read and approved the final manuscript.

\section{Funding}

The work was performed in the framework of the Program for State programs of the Ministry of Health of the Russian Federation for 2016-2022.

\section{Availability of data and materials}

All data generated or analyzed during this study are included in this published article.

\section{Declarations}

Ethics approval and consent to participate

The study was the study was carried out in compliance with the ARRIVE guidelines, and protocol of 052016 was approved by the local ethics committee at the N. N. Blokhin National Medical Research Center of Oncology.

All animal protocols have been approved by the Institutional Animal Care and Use Committee at the IBMC.

\section{Consent for publication}

All authors agree to publish the work.

\section{Competing interests}

The authors have no conflicts of interest to declare.

Received: 11 February 2021 Accepted: 31 March 2021

Published online: 10 April 2021

\section{References}

1. Denny WA. Emerging DNA topoisomerase inhibitors as anticancer drugs. Expert Opin Emerg Drugs. 2004;9(1):105-33. https://doi.org/10.1517/eoed. 9.1.105.32948.

2. Xu Y, Her C. Inhibition of topoisomerase (DNA) I (TOP1): DNA damage repair and anticancer therapy. Biomolecules. 2015;5(3):1652-70. https://doi.org/1 0.3390/biom5031652.

3. Borisova LM, Golubeva IS, Gorjunova OV, Eremina VA, Zhukova OS et al. NGlycosides of indolo [2,3-a]pyrrolo [3,4-c] carbazoles having antitumor activity. Patent RF, no 2548045, 2014. Available from: https://www1.fips.ru/ registers-doc-view/fips_servlet?DB=RUPAT\&DocNumber=2548045\&TypeFile= html.

4. Vartanjan AA, Baryshnikova MA, Eremina VA, Miniker TD, Tikhonova NI, Kuz'mina NE, Ehktova LV. Indolocarbazole derivative blocking tumors vasculogenic mimicry. Patent RF. no 2557554, 2014. Available from: https:// www1.fips.ru/registers-doc-view/fips_servlet?DB=RUPAT\&DocNumber= 2557554\&TypeFile=html.

5. Vartanian A, Golubeva I, Shprakh Z. Is Vasculogenic mimicry a Hallmark of an aggressive tumors? In "horizons in Cancer research". NY Nova Sci Publishers. 2017:65:13-34.

6. Vartanian A, Stepanova E, Grigorieva I, Solomka E, Baryshnikov A, Lichinitser M. VEGFR1 and PKCa signaling control melanoma vasculogenic mimicry in a VEGFR2 kinase-independent manner. Melanoma Res. 2011;21(2):91-8. https://doi.org/10.1097/CMR.0b013e328343a237.

7. Vartanian A, Baryshnikov A. Molecular determinants of tumorvasculogenic mimicry. In: Melanoma: molecular biology, risk factors and treatment options. USA: Nova Science Publishers: 2013. p. 67-92.

8. Hendrix MJ, Sefror EL, Hess AR, Seftor REB. Molecular plasticity of human melanoma cells. Oncogene. 2003;22(20):3070-5. https://doi.org/10.1038/sj. onc.1206447.

9. Azam F, Shavets M, Harris AD. Mechanisms of resistance to Antiangiogenesis therapy. Eur J Cancer. 2010;46(8):1323-32. https://doi.org/1 0.1016/j.ejca.2010.02.020

10. Plas DR, Thompson CB. Akt-dependent transformation: there is more to growth than just surviving. Oncogene. 2005;24(50):7435-42. https://doi. org/10.1038/sj.onc.1209097.

11. Vartanian A, Gatsina G, Grigorieva I, Solomko E, Dombrovsky V, Baryshnikov A, et al. The involvement of notch signaling in melanoma vasculogenic mimicry. Clin Exp Med. 2013;13(3):201-9. https://doi.org/10.1007/s10238012-0190-9.

12. Senderowicz AM. Inhibitors of cyclin-dependent kinase modulators for cancer therapy. Prog Drug Res. 2005:63:183-206. https://doi.org/10.1007/37643-7414-4_8. 
13. Vartanian AA, Burova OS, Stepanova EV, Baryshnikov AY, Lichinitser MR. Melanoma vasculogenic mimicry is strongly related to reactive pxygen species level. Melanoma Res. 2007;17(6):370-9. https://doi.org/10.1097/cmr. 0b013e3282f1d2ec.

14. Nock CJ, Brell JM, Bokar JA, Cooney MM, Cooper B, Gibbons J, et al. A phase I study of rebeccamycinanalog in combination with oxaliplatin in patients with refractory solid tumors. Investig New Drugs. 2011;29(1):126-30. https:// doi.org/10.1007/s10637-009-9322-9.

15. Saulnierv MG, Balasubramanian BN, Long BH, Frennesson DB, Ruediger E, Zimmermann $\mathrm{K}$, et al. Discovery of a fluoroindolo [2,3-a] carbazole clinical candidate with broad spectrum antitumor activity in preclinical tumor models superior to the marketed oncology drug, CPT-11. J Med Chem. 2005;48(7):2258-61. https://doi.org/10.1021/jm049090z.

16. Oh Y, Herbst RS, Burris H, Cleverly A, Musib L, Lahn M, et al. Enzastaurin, an oral, serine/threonine kinase inhibitor, as second- or third-line therapy of non-small cell lung cancer. J Clin Oncol. 2008;26(7):1135-41. https://doi. org/10.1200/JCO.2007.14.3685.

17. Pereira ER, Belin L, Sancelme M, Prudhomme M, Ollier M, Rapp M, et al. Structure - activity relationships in a series of substituted indolocarbazoles: topoisomerase I and protein kinase $\mathrm{C}$ ingibition and antitumoral and antimicrobial properties. J Med Chem. 1996;39(22):4471-7. https://doi.org/1 $0.1021 / \mathrm{jm} 9603779$

18. Mirzaei H, Sahebkar A, Avan A, Jaafari MR, Salehi R, et al. Application of mesenchymal stem cells in melanoma: a potential therapeutic strategy for delivery of targeted agents. Curr Med Chem. 2016;23(5):455-63. https://doi. org/10.2174/0929867323666151217122033.

19. Pourhanifeh MH, Abbaszadeh-Goudarzi K, Goodarzi M, Piccirillo SGM, Shafiee A, Hajighadimi S, et al. Resveratrol: a new potential therapeutic agent for melanoma? Curr Med Chem. 2021;28(4):687-711. https://doi.org/1 0.2174/0929867326666191212101225.

20. Mirzaei H, Salehi H, Oskuee RK, Mohammadpour A, Mirzaei HR, Sharifi MR, et al. The therapeutic potential of human adipose-derived mesenchymal stem cells producing CXCL10 in a mouse melanoma lung metastasis model. Cancer Lett. 2018;10(419):30-9. https://doi.org/10.1016/j.canlet.2018.01.029.

21. Mardani R, Hamblin MR, Taghizadeh M, Banafshe HR, Nejati M, Mokhtari M, et al. Nanomicellar-curcumin exerts its therapeutic effects via affecting angiogenesis, apoptosis, and T cells in a mouse model of melanoma lung metastasis. Pathol Res Pract. 2020;216(9):153082. https://doi.org/10.1016/j. prp.2020.153082.

22. Davoodvandi A, Darvish M, Borran S, Nejati M, Mazaheri S, Reza Tamtaji O, et al. The therapeutic potential of resveratrol in a mouse model of melanoma lung metastasis. Int Immunopharmacol. 2020;88:106905. https:// doi.org/10.1016/j.intimp.2020.106905.

23. Amiri A, Pourhanifeh MH, Mirzaei HR, Nahand JS, Moghoofei M, Sahebnasagh R, et al. Exosomes and lung Cancer: roles in pathophysiology, diagnosis and therapeutic applications. Curr Med Chem. 2021;28(2):308-28. https://doi.org/10.2174/0929867327666200204141952.

24. Bol'shakov OP, Neznanov NG, Babakhanyan RV. Didactic and ethical aspects of research on biomodels and laboratory animals. Kachestvennaya Klinicheskaya Praktika. 2002;1:58-61 https://www.clinvest.ru/jour/article/ view/249\#tab1.

25. Софьина 3.П., Сыркин АБ. Экспериментальная оценка противоопухолевых веществ в СССР и США. Москва: Медицина; 1980 г.

26. Миронов А.Н., редактор. Руководство по доклиническим исследованиям лекарственных средств, часть 1. М .: Гриф и К; 2012. с. 642-57.

27. Киселева М.П., Шпрах З.С., Борисова Л.М., Кубасова И.Ю., Ланцова А.В., Санарова Е.В. и др. Доклиническое исследование противоопухолевой активности производного N-гликозидов индолокарбазолов LCS-1208. Отчет I. Russ J Biother. 2015; 14 (2): 71-7. https://doi.org/10.17650/17269784-2015-14-2-71-77.

\section{Publisher's Note}

Springer Nature remains neutral with regard to jurisdictional claims in published maps and institutional affiliations.

Ready to submit your research? Choose BMC and benefit from:

- fast, convenient online submission

- thorough peer review by experienced researchers in your field

- rapid publication on acceptance

- support for research data, including large and complex data types

- gold Open Access which fosters wider collaboration and increased citations

- maximum visibility for your research: over $100 \mathrm{M}$ website views per year

At BMC, research is always in progress.

Learn more biomedcentral.com/submissions 